\title{
ANALISIS KESALAHAN DIKSI DAN KALIMAT DALAM SURAT DINAS PADA KANTOR WALI KOTA MAKASSAR PROVINSI SULAWESI SELATAN
}

\author{
DICTION AND SENTENCE ERROR ANALYSIS \\ OF OFFICIAL LETTERS IN MAYOR OFFFICE \\ OF MAKASSAR SOUTH SULAWESI
}

\author{
M. Asri B. \\ Balai Bahasa Provinsi Sulawesi Tengah \\ Jalan Untad I, Bumi Roviga, Tondo, Palu 94118 \\ Telepon (0451) 4705498; 421874 Pos-el: asritoroviga@ymail.com
}

\begin{abstract}
Aspects of language in official letter is a very vital thing. It's possible because through language, important official information can be well achieved. Therefore, the language in the official letters needs to be organized in such a way. The method used in this research was descriptive analytical method with documentation technique. The purpose of this study was to describe the forms of diction and sentences errors in official letters in Makassar's Mayor Office. The results obtained were the findings of thirteen errors of language comprising six forms of diction errors together with 7 forms of sentence errors.
\end{abstract}

Keywords: error analysis, diction, sentence, official letters, Makassar's Mayor office

\begin{abstract}
Abstrak
Aspek kebahasaan dalam surat dinas merupakan suatu hal yang sangat vital. Hal itu memungkinkan kerena melalui bahasa, informasi-informasi penting antarkedinasan dapat tercapai dengan baik. Oleh karena itu, bahasa dalam surat dinas perlu ditata sedemikian rupa. Metode yang digunakan dalam penelitian ini adalah metode deskriptif analitis dengan teknik dokumentasi. Tujuan penelitian ini adalah mendeskripsikan bentuk kesalahan diksi dan kalimat dalam surat dinas di Kantor Wali Kota Makassar. Hasil penelitian yang didapatkan adalah ditemukan tiga belas kesalahan berbahasa, yang terbagi atas enam bentuk kesalah diksi dan tujuh bentuk kesalahan kalimat.
\end{abstract}

Kata Kunci: analisis kesalahan, diksi, kalimat, surat dinas, kantor Wali Kota Makassar 


\section{Latar Belakang}

Bahasa memegang peranan penting dalam kelangsungan hidup manusia. Pentingnya bahasa itu hampir mencakup segala bidang kehidupan manusia. Melalui bahasa, manusia berkomunikasi dengan manusia lain untuk berbagai keperluan dalam kehidupannya, baik secara lisan maupun tulis. Salah satu sarana yang digunakan untuk berkomunikasi secara tertulis adalah melalui surat. Sebagai sarana berkomunikasi tertulis, surat paling tidak melibatkan dua pihak, yaitu pengirim dan penerima surat. Di samping itu, surat sebagai sarana komunikasi dapat juga disampaikan secara resmi maupun tidak resmi.

Surat yang disampaikan secara resmi biasanya disebut surat dinas. Bahasa surat dinas atau surat resmi adalah ragam tulisan. Ini berarti bahasanya sudah memiliki tata tulis yang secara teratur dipakai dalam ragam tulisan. Dalam surat dinas, juga terkandung informasi-informasi tertentu yang dapat berupa perintah, pemberitahuan, tugas, permintaan, teguran dan lain-lain. Oleh karena itu, surat hendaknya ditulis menggunakan bahasa yang efektif, bahasa yang baik dan benar sesuai dengan kaidah bahasa Indonesia yang berlaku. Kesalahan-kesalahan yang sering terjadi dalam penulisan surat dinas adalah penggunaan bahasa yang tidak baku.

Oleh karena itu, dalam penggunaan ragam bahasa baku tulis diperlukan kecermatan dan ketepatan di dalam pemilihan kata, penerapan kaidah ejaan, struktur bentuk kata dan struktur kalimat, serta unsurunsur bahasa di dalam struktur kalimat.

Akan tetapi, dalam kenyataannya, menulis surat dinas tidak mudah dilakukan. Masih banyak ditemukan bahasa surat dinas yang tidak sesuai dengan kaidah bahasa yang baku sehingga menyebabkan kesalahan bahasa. Berdasarkan pengamatan awal, kesalahan penggunaan bahasa Indonesia dalam surat ini juga terdapat pada surat dinas di Kantor Wali Kota Makassar Sulawesi Selatan.

Berdasarkan latar belakang tersebut,pada penelitian ini penulis merumuskan masalah: bagaimanakah bentuk kesalahan diksi dan kalimat dalam surat dinas di Kantor Wali Kota Makassar Provinsi Sulawesi Selatan?

Gramatika, Volume II, Nomor 1, Januari-Juni 2014

\section{Landasan Teori}

\subsection{Analisis Kesalahan Berbahasa}

Analisis kesalahan berbahasa merupakan salah satu cara mengetahui seberapa jauh kemampuan sesorang menggunakan bahasa Indonesia dengan baik dan benar. Berkaitan dengan ini, Tarigan, 1988: 141 menjelaskan bahwa analisis kesalahan berbahasa adalah salah satu cara untuk menjawab bagaimana menggunakan bahasa Indonesia yang baik dan benar. Kesalahan berbahasa merupakan sisi yang mempunyai cacat pada ujaran atau tulisan. Kesalahan tersebut merupakan bagian-bagian konversasi atau komposisi yang menyimpang dari norma baku atau norma terpilih dan performasi bahasa orang dewasa .

Selanjutnya, Norish (1983: 6-8) menguraikan tiga tipe penyimpangan berbahasa, yaitu error, mistake, dan lapse. Ketiga tipe itu akan terurai seperti berikut.

a. Error (kesalahan) merupakan penyimpangan berbahasa secara sistematis dan terus-menerus sebagai akibat belum dikuasainya kaidahkaidah atau norma-norma bahasa target.

b. Mistake, (kekeliruan) terjadi ketika seorang pembelajar tidak secara konsisten melakukan penyimpanagn dalam berbahasa. Kadang-kadang pembelajar dapat mempergunakan kaidah/norma yang benar tetapi kadang-kadang mereka membuat kekeliruan dengan mempergunakan kaidah/norma dan bentuk-bentuk yang keliru.

c. Lapse (selip lidah) diartikan sebagai bentuk penyimpangan yang diakibatkan karena pembelajar kurang konsentrasi, rendahnya daya ingat atau sebab-sebab lain yang dapat terjadi kapan saja dan pada siapa pun.

\subsection{Pengertian Surat}

Surat adalah informasi tertulis yang dapat dipergunakan sebagai alat komunikasi tulis yang dibuat dengan persyaratan tertentu yang khusus berlaku untuk surat menyurat (Finoza, 2005: 4). Hal senada disampaikan oleh Sudarsa, dkk. (1992: 3) yang mengemukakan bahwa surat adalah suatu sarana komunikasi yang digunakan untuk menyampaikan informasi tertulis oleh suatu pihak kepada pihak lain. 
Selanjutnya, Bratawidjaja(1995: 5) menjelaskan pula bahwa surat adalah satu sarana untuk menyampaikan pernyataan atau informasi itu dapat berupa pemberitahuan, pernyataan, permintaan, laporan, pemikran, sanggahan dan sebagainya. Informasi tersebut dapat berupa pemberitahuan, pernyataan, perintah, dan keterangan. Informasi dalam surat diperlukan sebagai media komunikasi karena dapat mengurangi terjadinya kesalahpahaman dalam berkomunikasi dan berinteraksi. Suatu instansi pemerintah menggunakan surat sebagai media komunikasi efektif yang tidak dapat ditinggalkan, yaitu surat dinas.

Untuk memperjelas lagimengenai definisi surat, Soedjito dan Solchan (1994: 1) menjelaskan pula bahwa surat adalah jenis karangan (komposisi) paparan. Di dalam paparan pengarang mengemukakan maksud dan tujuannya, menjelaskan apa yang dipikirkan dan dirasakannya. Demikian pula di dalam surat. Selain itu, surat adalah percakapan (dialog) seperti yang biasa dipakai dalam kehidupan seharihari.

Di samping itu, Surat dinas memiliki berbagai fungsi yaitu sebagai berikut:(a) surat sebagai utusan atau wakil penulis/instansi pengirimnya; (b)surat sebagai bukti tertulis, misalnya surat perjanjian; (c) surat sebagai alat pengikat karena dapat diarsipkan dan dilihat kembali bila diperlukan (d) surat sebagai bukti sejarah, misalnya surat-surat yang memuat perubahan atau perkembangan suatu organisasi/perusahaan; (e) surat sebagai pedoman kerja, misalnya surat keputusan atau instruksi tentang juklak; dan (f) surat sebagai jaminan keamanan, misalnya surat jalan (Mustakim, 1994: 161). Dengan demikian, penulisan surat dinas harus memperhatikan aspek-aspek kebahasaannya agar informasi yang ingin disampaikan oleh si pengirim surat dapat diterima dengan baik pula oleh si penerima surat.

\subsection{Diksi}

Diksi adalah pilihan kata, maksudnya kita memilih kata yang tepat untuk mengungkapkan sesuatu (Keraf, 1994: 22). Kata yang tepat dapat membantu seseorang mengungkapkan dengan tepat apa yang ingin disampaikannya, baik secara lisan maupun tulisan. Selain itu, pemilihan kata harus pula sesuai dengan situasi dan tempat penggunaan kata-kata tersebut.

Menurut Keraf(1994:24), ada tiga kesimpulan utama dalam diksi, yaitu, pertama, pilihan kata atau diksi mencakup pengertian kata-kata mana yang dipakai untuk menyampaikan suatu gagasan, bagaimana pengelompokkan kata-kata yang tepat atau menggunakan ungkapan-ungkapan yang tepat, dan gaya mana yang paling baik digunakan dalam suatu situasi. Kedua, pilihan kata atau diksi adalah kemampuan membedakan secara tepat nuansa-nuansa makna dari gagasan yang ingin disampaikan, dan kemampuan untuk menemukan bentuk yang sesuai (cocok) dengan situasi dan nilai rasa yang dimiliki kelompok masyarakat pendengar. Ketiga, pilihan kata yang tepat dan yang sesuai hanya dimungkinkan oleh penguasaan sejumlah besar kosakata atau perbendaharaan kata bahasa itu. Sementara itu, yang dimaksud perbendaharaan kata atau kosakata suatu bahasa adalah keseluruhan kata yang memiliki........? oleh sebuah kata."

Pilihan kata ini sangat penting dalam penulisan surat. Jika terjadi kesalahan dalam pemilihan kata ini, akan berakibat pada pemahaman yang berbeda dengan penerima surat. Artinya, informasi yang ingin disampaikan tidak dapat diterima dengan baik oleh si penerima surat. Oleh karena itu, alangkah indahnya apabila para pelaku surat menyurat itu memiliki wawasan yang memadai perihal kosa kata dan perbendaharaan kata.

\subsection{Kalimat}

Selain diksi, pemakaian kalimat juga perlu diperhatikan dalam menulis surat. Menururt Arifin dan Mustakim (2005: 82), kalimat-kalimat yang digunakan dalam surat dinas hendaknya berupa kalimat efektif, yaitu kalimat yang sesuai dengan kaidah bahasa, singkat dan enak dibaca. Kalimat yang sesuai dengan kaidah bahasa adalah kalimat yang tidak menyimpang dari kaidah ketatabahasaan yang berlaku.

Dalam KBBI (2008), dijelaskan bahwa kalimat adalah (1) kesatuan ujar yg mengungkapkan suatu konsep pikiran dan perasaan; (2) perkataan; (3) satuan bahasa yg secara relatif berdiri sendiri, mempu- 
nyai pola intonasi final. Senada dengan hal itu, Arifin dan Tasai (2010: 66) juga menambahkan bahwa kalimat adalah satuan bahasa terkecil, dalam wujud lisan atau tulisan, yang mengungkapkan pikiran yang utuh. Dalam wujud tulisan huruf latin, kalimat dimulai dengan huruf kapital dan diakhiri dengan tanda titik atau tanda tanya maupun tanda seru.

Dari beberapa pendapat di atas, dapat disimpulkan bahwa kalimat merupakan suatu bentuk bahasa untuk menyapaikan pikiran atau perasan seorang, seperti percakapan, selalu terjadi dari sejumlah kalimat yang saling berhubungan satu dengan yang lainnya dan dengan cara teratur.

\section{Metode Penelitian}

Metode yang digunakan dalam penelitian ini adalah metode deskriptifanalitis. Arikunto (2010: 3) menjelaskan metode deskriptif merupakan penelitian yang benar-benar hanya memaparkan apa yang terdapat atau terjadi dalam sebuah lapangan, atau wilayah tertentu.

Dalam penelitian ini, penulis menggunakan metode deskriptifanalitis dengan tujuan agar dapat mendeskripsikan kesalahan diksi dan kalimat dalam surat dinas di kantor Wali Kota Makassar.

Sumber data dalam penelitian ini adalah surat dinas yang diarsipkan oleh staf tata usaha pada Kantor Walikota Makassar di Provinsi Sulawesi Selatan.

Teknik pengumpulan data yang penulis gunakan dalam penelitian ini adalah teknik dokumentasi. Arikunto (2010: 274) menjelaskan bahwa teknik dokumentasi adalah teknik yang digunakan untuk mencari data, hal-hal variabel yang berupa catatan, bukubuku, majalah, surat kabar, majalah, prasasti, notulen rapat dan lain-lain”. Dokumen yang digunakan dalam penelitian ini adalah surat keluar edisi Desember 2011-Januari 2012 yang diarsipkan oleh staf tata usaha pada Kantor Wali Kota Makassar di Provinsi Sulawesi Selatan.

Adapun langkah kerja yang dilakukan penulis sebagai berikut.

a. Menfoto kopi surat dinas yang diarsipkan oleh staf tata usaha pada Kantor Wali Kota Makassar di Provinsi Sulawesi Selatan.

Gramatika, Volume II, Nomor 1, Januari-Juni 2014 b. Membuat catatan yang berkaitan kesalahan diksi dan kalimat dalam surat dinas pada Kantor Wali Kota Makassar di Provinsi Sulawesi Selatan.

Berdasarkan metode penelitian yang peneliti gunakan dan objek penelitian berupa surat dinas yang diarsipkan oleh staf tata usaha pada Kantor Wali Kota Makassar di Provinsi Sulawesi Selatan, data juga dianalis dengan lima cara. Kelima cara itu adalah sebagai berikut.

a. Mengidentifikasi kesalahan diksi dan kalimat dalam surat dinas.

b. Mengklasifikasi kesalahan diksi dan kalimat dalam surat dinas.

c. Menganalisis kesalahan diksi dan kalimat dalam surat dinas.

d. Membahas hasil analisis.

e. Kesimpulan

\subsection{Pembahasan}

Pembahasan hasil penelitian dilakukan dengan mengidentifikasi dan membuat klasifikasi data dari setiap aspek penyimpangan. Jumlah data yang diperoleh secara keseluruhan adalah 21 surat resmi yang dikeluarkan oleh Bagian Pemerintahan dan Bagian Umum di Kantor Walikota Makassar.

Selanjutnya, perolehan data tersebut dianalisis dengan menggunakan pendekatan deskriptifkualitatif dengan langkah-langkah sebagai berikut.

(1) Mengidentifikasi penyimpangan kebakuan penggunaan bahasa, yang meliputi penyimpangan diksi dan kalimat terhadap dokumen resmi (surat resmi) yang dikeluarkan oleh kantor Walikota Makassar.

(2) Mengklasifikasi penyimpangan kebakuan penggunaan bahasa, yang meliputi penyimpangan penggunaan diksi dan kalimat terhadap dokumen resmi (surat resmi) yang dikeluarkan oleh kantor Walikota Makassar.

\subsubsection{Identifikasi Data}

Identifikasi data adalah suatu proses untuk menentukan atau menetapkan identitas data yang diteliti. Yang menjadi data dalam penelitian ini adalah suratsurat dinas/resmi yang dikeluarkan oleh kantor Wali- 
kota Makassar. Oleh karena itu, sasaran indetifikasi adalah aspek-aspek penyimpangan kebahasaan yang terdapat dalam data-data surat resmi yang ada di kantor Walikota Makassar.
Adapun hasil identifikasi data aspek kebahasaan yang meliputi (1) diksi atau pilihan kata dan (2) kalimat. Hal itu dapat dilihat pada tabel 1 berikut.

Tabel 1

Identifikasi Aspek-Aspek Penyimpangan

Diksi atau Pilihan Kata dan Kalimat

\begin{tabular}{|c|l|}
\hline No. & \multicolumn{1}{|c|}{ Data } \\
\hline & Penyimpangan Diksi (Pilihan Kata) \\
\hline 1. & Pada saat melakukan kordinasi rancangan Peraturan/Keputusan... \\
\hline 2. & $\begin{array}{l}\text { Bagi pimpinan SKPD yang tidak mengindahkan isi Surat Edaran ini } \\
\text { adalah merupakan perbuatan bertentangan dengan pasal 3 angka 11 } \\
\text { peraturan pemerintah Nomor 53 tahun 2010 tentang Peratura Pegawai } \\
\text { Negeri Sipil. }\end{array}$ \\
\hline 3. & $\begin{array}{l}\text { Dengan hormat, bersama ini kami mengundang Bapak/Ibu/Saudara (i) } \\
\text { untuk menghadiri acara yang akan dilaksanakan pada: }\end{array}$ \\
\hline 4. & $\begin{array}{l}\text { Laporan dimaksud berupa laporan keuangan SKPD yang terdiri dari } \\
\text { Laporan Realisasi Anggaran (LRA), Neraca, CALK, .... }\end{array}$ \\
\hline 5. & Jam : 09.00 Wita \\
\hline 6. & $\begin{array}{l}\text { Dalam Rangka Pelaksanaan Hari Kedisiplinan Nasional yang } \\
\text { dilaksanakan setiap tanggal 17 bulan berjalan.... }\end{array}$ \\
\hline 1. & Penyimpangan Penggunaan Kalimat \\
\hline 2. & $\begin{array}{l}\text { Denunjuk surat dari Kepala Balitbangda Propinsi Sulawesi Selatan.... } \\
\text { untuk menghadiri acara yang akan dilaksanakan pada: }\end{array}$ \\
\hline 3. & $\begin{array}{l}\text { Dengan hormat, kami mengundang Bapak/Ibu/Saudara (i) untuk } \\
\text { menghadiri acara yang akan dilaksanakan pada: }\end{array}$ \\
\hline 4. & $\begin{array}{l}\text { Demikian disampaikan atas perhatiannya diucapkan terima kasih. } \\
\text { (Sumber: Sekretaris Daerah Kota , 6 Desember 2012). }\end{array}$ \\
\hline 5. & Demikian disampaikan untuk pelaksanaan. \\
\hline 6. & $\begin{array}{l}\text { Demikian disampaikan kepada Bapak untuk dimaklumi dan selanjutnya } \\
\text { yang bersangkutan melaporkan hasilnya kepada Walikota Makasar Cq. } \\
\text { Kepala Kantor Kesatuan Bangsa dan Perlindungan Masyarakat. }\end{array}$ \\
\hline 7. & Demikian disampaikan untuk menjadi perhatian, terima kasih. \\
\hline
\end{tabular}

\subsection{Klasifikasi Data}

Klasifikasi ini merupakan proses yang bersifat alamiah untuk menampilkan kaidah penyimpangan pada beberapa aspek ke dalam kelas-kelas tertentu karena adanya kesamaan ciri-ciri penyimpangan kaidah. Hal ini merupakan kegiatan penalaran yang peneliti usahakan untuk menjawabnya sesuai dengan rumusan masalah dan tujuan penelitian. Lebih jelasnya, penyimpangan beberapa aspek kebahasaan tersebut di atas dapat dilihat pada tabel berikut ini. 


\subsubsection{Tipe Penyimpangan Diksi (Pilihan Kata)}

Tabel 2 Klasifikasi Aspek-aspek Bentuk Penyimpangan Diksi (Pilihan Kata)

\begin{tabular}{|c|c|c|}
\hline No. & Data & $\begin{array}{c}\text { Cara Penulisan Menurut Kaidah Bahasa } \\
\text { Indonesia }\end{array}$ \\
\hline 1. & $\begin{array}{l}\text { Pada saat melakukan kordinasi rancangan } \\
\text { Peraturan/Keputusan... }\end{array}$ & $\begin{array}{l}\text { Pada saat melakukan koordinasi rancangan } \\
\text { Peraturan/Keputusan... }\end{array}$ \\
\hline 2. & $\begin{array}{l}\text { Bagi pemimpin SKPD yang tidak } \\
\text { mengindahkan isi Surat Edaran ini adalah } \\
\text { merupakan perbuatan bertentangan dengan } \\
\text { pasal } 3 \text { angka } 11 \text { peraturan pemerintah Nomor } \\
53 \text { tahun } 2010 \text { tentang Peraturan Pegawai } \\
\text { Negeri Sipil. }\end{array}$ & $\begin{array}{l}\text { Bagi pemimpin SKPD yang tidak mengindahkan } \\
\text { isi Surat Edaran ini merupakan perbuatan } \\
\text { bertentangan dengan pasal } 3 \text { angka } 11 \text { peraturan } \\
\text { pemerintah Nomor } 53 \text { tahun } 2010 \text { tentang } \\
\text { Peraturan Pegawai Negeri Sipil. } \\
\text { Bagi pemimpin SKPD yang tidak mengindahkan } \\
\text { isi Surat Edaran ini adalah perbauatan } \\
\text { bertentangan dengan pasal } 3 \text { angka } 11 \text { peraturan } \\
\text { pemerintah Nomor } 53 \text { tahun } 2010 \text { tentang } \\
\text { Peratura Pegawai Negeri Sipil. }\end{array}$ \\
\hline 3. & $\begin{array}{l}\text { Dengan hormat, bersama ini kami } \\
\text { mengundang Bapak/Ibu/Saudara (i) untuk } \\
\text { menghadiri acara yang akan dilaksanakan } \\
\text { pada: }\end{array}$ & $\begin{array}{l}\text { Dengan hormat, bersama ini kami mengundang } \\
\text { Bapak untuk menghadiri acara yang akan } \\
\text { dilaksanakan pada: } \\
\text { Dengan hormat, bersama ini kami mengundang } \\
\text { Ibu untuk menghadiri acara yang akan } \\
\text { dilaksanakan pada: } \\
\text { Dengan hormat, bersama ini kami mengundang } \\
\text { Bapak/Ibu untuk menghadiri acara yang akan } \\
\text { dilaksanakan pada: } \\
\text { Dengan hormat, bersama ini kami mengundang } \\
\text { Saudara untuk menghadiri acara yang akan } \\
\text { dilaksanakan pada: }\end{array}$ \\
\hline 4. & $\begin{array}{l}\text { Laporan dimaksud berupa laporan keuangan } \\
\text { SKPD yang terdiri dari Laporan Realisasi } \\
\text { Anggaran (LRA), Neraca, CALK, .... }\end{array}$ & $\begin{array}{l}\text { Laporan dimaksud berupa laporan keuangan } \\
\text { SKPD yang terdiri atas Laporan Realisasi } \\
\text { Anggaran (LRA), Neraca, CALK, .... }\end{array}$ \\
\hline 5. & Jam: 09.00 Wita & pukul: $09.00 \mathrm{Wita}$ \\
\hline 6. & $\begin{array}{l}\text { Dalam Rangka Pelaksanaan Hari Kedisiplinan } \\
\text { Nasional yang dilaksanakan setiap tanggal } 17 \\
\text { bulan berjalan.... }\end{array}$ & $\begin{array}{l}\text { Dalam Rangka Pelaksanaan Hari Kedisiplinan } \\
\text { Nasional yang dilaksanakan setiap tanggal } 17 \\
\text { kata saat itu atau bulan tersebut. }\end{array}$ \\
\hline
\end{tabular}

Kesalaha diksi yang terjadi pada contoh(1) di atas adalah adanya penggunaan kata kordinasi yang tidak tepat. Kata yang benar sesuai dengan kiadah bahasa Indonesia adalah koordinasi. Dalam KBBI (2008), sudah tertera bahwa penulisan yang benar adalah koordinasi yang berarti: perihal mengatur suatu organisasi atau kegiatan sehingga peraturan dan

Gramatika, Volume II, Nomor 1, Januari-Juni 2014 tindakan yang akan dilaksanakan tidak saling bertentangan atau simpang siur.

Dengan demikian, kesalahan yang terdapat pada contoh (1) di atas dapat diperbaiki sebagai berikut.

1a. Pada saat melakukan koordinasi rancangan Peraturan/Keputusan...

2. Bagipemimpin SKPD yang tidak mengindahkan isi Surat Edaran ini adalah merupakan perbuatan 
bertentangan dengan pasal 3 angka 11 peraturan pemerintah Nomor 53 tahun 2010 tentang Peratura Pegawai Negeri Sipil. (Sumber: Sekretariat Daerah Kota, 17 Januari 2013).

Kesalahan diksi yang terdapat pada contoh (2) di atas disebkan oleh adanya dua ungkapan bersinonim yang digunakan secara bersamaan. Seharus, kedua ungkapan tersebut tidak digunakan berbarengan tapi dipilih salah satu di antaranya. Berkaitan dengan hal itu, Arifin (1996: 61) menjelaskan bahwa ungkapan-ungkapan yang bersinonim tidak digunakan sekaligus karena penggunaan dua kata yang berarti sama penulisan yang mubazir.

Misalnya:

sejak dan dari

adalah dan merupakan

demi dan untuk

agar dan supaya

Dengan demikian, kesalahan penggunaan diksi pada contoh (2) dapat diperbaiki sebagai berikut.

(2a) Bagi pemimpin SKPD yang tidak mengindahkan isi Surat Edaran ini adalah perbuatan bertentangan dengan Pasal 3 Angka 11 Peraturan Pemerintah Nomor 53 tahun 2010 tentang Peratura Pegawai Negeri Sipil.

(2b) Bagi pemimpin SKPD yang tidak mengindahkan isi Surat Edaran ini merupakan perbauatan bertentangan dengan pasal 3 angka 11 peraturan pemerintah Nomor 53 tahun 2010 tentang Peratura Pegawai Negeri Sipil.

3. Dengan hormat, bersama ini kami mengundang Bapak/Ibu/Saudara (i) untuk menghadiri acara yang akan dilaksanakan pada:

Kesalahan yang terdapat dalam contoh (3) adalah dicantumkannya secara bersamaan kata penyapa dalam satu surat. Lumintaintang (2007: 66) menjelaskan bahwa kata penyapa yang lazim dipakai di dalam laras surat dinas adalah Bapak, Ibu, Saudara, dan Anda. Pemakaian keempat kata penyapa itu sangat bergantung pada status dan peran penulis dan penerima surat. Penyapa Bapak dan Ibu merupakan kata penyapa yang respektif/hormat. Kedua kata itu cenderung berdimensi sosial jarak, yaitu jika penulis dan

penerima surat mempunyai peran yang jauh. Kedua kata itu merupakan kata yang memiliki kadar "rasa hormat" yang tinggi di dalam birokrasi persuratan dinas kita. Untuk hubungan yang horisontal/karib/ dekat lazim digunakan kata Anda. Penyapa Saudara lazim dipakai dalam hubungan peran yang vertikal tetapi dari atas ke bawah. Perbaikan kalimat (3) seperti berikut.

3a. Dengan hormat, bersama ini kami mengundang Bapak untuk menghadiri acara yang akan dilaksanakan pada:

3b. Dengan hormat, bersama ini kami mengundang Ibu untuk menghadiri acara yang akan dilaksanakan pada:

3c. Dengan hormat, bersama ini kami mengundang Bapak/Ibu untuk menghadiri acara yang akan dilaksanakan pada:

3d. Dengan hormat, bersama ini kami mengundang Saudara untuk menghadiriacara yang akan dilaksanakan pada:

4. Laporan dimaksud berupa laporan keuangan SKPD yang terdiri dari Realisasi Anggaran (LRA), Neraca, CALK, .... (Sumber: Walikota Makassar, 15 Januari 2013).

Kesalahan yang terdapat pada contoh (4) adalah kesalahan penggunaan diksi, khususnya yang berkaitan dengan ungkapan idiomatik. Arifin (2010: 49) menjelaskan bahwa ungkapan idiomatik adalah konstruksi yang khas pada suatu bahasa yang salah satu unsurnya tidak dapat dihilangkan atau diganti. Ungkapan idiomatik adalah kata-kata yang mempunyai sifat idiom yang tidak kena ekonomi bahasa. Ungkapan idiomatik bersifat idiomatik terdiri atas dua atau tiga kata yang dapat memperkuat diksi di dalam tulisan.

Misalnya:

Salah

terdiri dari

terjdi atas

disebabkan karena

Dengan demikian, kesalahan penggunaan diksi pada contoh (4) dapat diperbaiki sebagai berikut 
(4a) Laporan dimaksud berupa laporan keuangan SKPD yang terdiri atas Laporan Realisasi Anggaran(LRA), Neraca, CALK, ....

5. Jam: 09.00 Wita (Sumber: Sekretariat Daerah Kota, 28 Januari 2013).

Penulisan kata jam pada contoh di atas tidak tepat. Kata jam digunakan untuk menyatakan rentang waktu atau nama benda penunjuk waktu. Adapun kata pukul bermakna penunjuk waktu. Berkaitan dengan itu, Arifin (2010: 34) menjelaskan bahwa pemakaian kata pukul dan jam harus dilakukan secara tepat. Kata pukul menunjukkan waktu sedangkan kata jam menunjukkan jangka waktu. Misalnya:

Seminar tentang kardiologi yang diselenggarakan oleh Fakultas Kedokteran Universitas Indonesia berlangsung selama 4 jam, yaitu dari pukul 8.00 s.d. pukul 12.00 .
Dengan demikian, kesalahan penggunaan diksi pada contoh (5) dapat diperbaiki sebagai berikut.

(5a) Pukul: 09.00 Wita

6. Dalam Rangka Pelaksanaan Hari Kedisiplinan Nasional yang dilaksanakan setiap tanggal 17 bulan berjalan....

Penulisan kata bulan berjalan pada contoh (6) di atas adalah tidak tepat. Ungkapan bulan berjalan bermakna ambigu dan tidak tepat digunakan dalam bahasa surat dinas yang sifatnya resmi. Dalam KBBI (2008), berjalan diartikan (a) melangkahkan kaki bergerak maju; (b) bergerak maju dr suatu titik (tempat) ke titik (tempat) lain; (c)menggelinding atau berputar (tentang sesuatu yang bundar sepeti roda); (d) bepergian.

Berdasarkan hal itu, kesalahan pada contoh kalimat (6) di atas dapat diperbaiki sebagai berikut.

6a. Dalam Rangka Pelaksanaan Hari Kedisiplinan Nasional yang dilaksanakan setiap tanggal 17 saat itu atau bulan tersebut.

\section{Tipe Penyimpangan Kalimat}

Tabel III Klasifikasi Aspek- aspek Bentuk Penyimpangan Kalimat

\begin{tabular}{|c|c|c|}
\hline No. & Data & Cara Penulisan Menurut EYD \\
\hline 1. & $\begin{array}{l}\text { Menunjuk surat dari Kepala Balitbangda } \\
\text { Propinsi Sulawesi Selatan.... }\end{array}$ & $\begin{array}{l}\text { Sejalan dengan surat dari Kepala Balitbangda } \\
\text { Provinsi Sulawesi Selatan.... }\end{array}$ \\
\hline 2. & $\begin{array}{l}\text { Dengan hormat, bersama ini kami } \\
\text { mengundang Bapak/Ibu/Saudara (i) untuk } \\
\text { menghadiri acara yang akan dilaksanakan } \\
\text { pada: }\end{array}$ & $\begin{array}{l}\text { Dengan hormat, dengan ini kami } \\
\text { mengundang Bapak/Ibu/Saudara (i) untuk } \\
\text { menghadiri acara yang akan dilaksanakan } \\
\text { pada: }\end{array}$ \\
\hline 3. & $\begin{array}{l}\text { Dengan hormat, kami mengundang } \\
\text { Bapak/Ibu/Saudara (i) untuk menghadiri } \\
\text { acara yang akan dilaksanakan pada: }\end{array}$ & $\begin{array}{l}\text { (3a) Dengan hormat, } \\
\text { Kami mengundang Bapak untuk } \\
\text { menghadiri acara yang akan } \\
\text { dilaksanakan pada: } \\
\text { (3b) Dengan hormat, } \\
\text { Kami mengundang Ibu untuk } \\
\text { menghadiri acara yang akan } \\
\text { dilaksanakan pada: } \\
\text { (3c) Dengan hormat, } \\
\text { Kami mengundang Saudara untuk } \\
\text { menghadiri acara yang akan } \\
\text { dilaksanakan pada: }\end{array}$ \\
\hline
\end{tabular}




\begin{tabular}{|c|l|l|}
\hline 4. & $\begin{array}{l}\text { Demikian disampaikan atas perhatiannya } \\
\text { diucapkan terima kasih. (Sumber: } \\
\text { Sekretaris Daerah Kota , 6 Desember } \\
\text { 2012). }\end{array}$ & $\begin{array}{l}\text { (4a) Demikian disampaikan atas } \\
\text { perhatian Saudara, kami ucapkan } \\
\text { terima kasih. } \\
\text { (4b) Demikian disampaikan atas } \\
\text { perhatian Anda, kami ucapkan } \\
\text { terima kasih. } \\
\text { (4c) Demikian disampaikan atas } \\
\text { perhatian Bapak, kami ucapkan } \\
\text { terima kasih. }\end{array}$ \\
\hline 5. & Demikian disampaikan untuk pelaksanaan. & $\begin{array}{l}\text { (4d) Demikian harapan kami, semoga } \\
\text { Bapak dapat melaksnakan tugas ini } \\
\text { dengan baik. }\end{array}$ \\
\hline 6. & $\begin{array}{l}\text { Demikian penyampaian kami, atas perhatian } \\
\text { Bapak, kami ucapkan terima kasih. }\end{array}$ \\
\hline 7. & $\begin{array}{l}\text { Derak dimaklumi dan selanjutnya yang } \\
\text { Wersangkutan melaporkan hasilnya kepada } \\
\text { perhatian, terima kasih. }\end{array}$ & $\begin{array}{l}\text { Demikian penyampaian kami, atas perhatian } \\
\text { Bapak, kami ucapkan terima kasih. }\end{array}$ \\
\hline
\end{tabular}

Kalimat yang digunakan dalam surat dinas hendaknya berupa kalimat efektif, yaitu kalimat yang sesuai dengan kaidah bahasa, singkat, dan enak dibaca. Kalimat yang sesuai dengan kaidah bahasa Indonesia adalah kalimat yang tidak menyimpang dari kaidah yang berlaku. Kalimat itu sekurang-kurangnya memiliki subjek(S) dan predikat (P). Selain itu, kalimat yang digunakan adalah kalimat yang tidak berteletele atau tidak berbelit-belit. Namun, tidak berarti bahwa unsur-unsur wajib yang ada dalam kalimat boleh dihilangkan. Selanjutnya, kalimat diusahakan kalimat yang mengandung nada sopan dan simpatik dan hindari yang bernada menghina atau meremehkan pembaca.

Berdasarkan data yang ada, ditemukan beberapa kesalahan penulisan kalimat dalam surata dinas di Kantor Wali Kota Makasar, sebagai berikut.

1. Menunjuk surat dari Kepala Balitbangda Provinsi Sulawesi Selatan.... (Kesbang, 4 Desember 2012).

Kesalahan yang terdapat pada contoh (1) disebabkan oleh struktur kalimat tersebut dipengaruhi oleh bahasa asing karena anak kalimat menunjuk surat dari pada contoh (1) tidak menggunakan kata penanda anak kalimat. Di samping itu, kata menunjuk juga salah dari segi makna semantisnya. Dalam KBBI (2008) diartikan bahwa menunjuk bermakna mengacungkan jari telunjuk ke .... Akan tetapi, berbeda yang dimaksudkan dalam surat tersebut. Yang dimaksudkan dalam surat tersebut bukan menujuk melainkan merujuk, berdasarkan, atau sejalan. Jika ingin mengikuti kaidah bahasa Indonesia dengan benar, struktur kalimat seperti itu mesti dihindari. Sebaiknya kalimat (1) diubah menjadi berikut.

(1a) Sejalan dengan surat dari Kepala Balitbangda Provinsi Sulawesi Selatan....

2. Dengan hormat, bersama ini kami mengundang Bapak/Ibu/Saudara (i) untuk menghadiri acara yang akan dilaksanakan pada: (Sumber: Sekretariat Daerah Kota, 9 Januari 2013).

Kalimat (2) di atas tidak benar karena isinya hanya mengundang dan surat tersebut tidak menyertakan sesuatu, tidak melampirakan berkas, atau tidak mengirimkan apa-apa. Ungkapan bersama ini digunakan jika surat melampirkan sesuatu atau menyertakan barang, dan sebagainya (Arifin, 1996: 68).

Oleh karena itu, kalimat (2) harus diubah sebagai berikut. 
(2a) Dengan hormat, dengan ini kami mengundang Bapak/Ibu/Saudara (i) untuk menghadiri acara yang akan dilaksanakan pada:

3. Dengan hormat, kami mengundang Bapak/Ibu/ Saudara (i) untuk menghadiri acara yang akan dilaksanakan pada: (Sumber: Sekretariat Daerah Kota, 14 Desember 2012).

Kesalahan yang terdapat pada contoh (3) karena ungkapan dengan hormat yang digunakan sebagai ucapan salam penulis surat untuk penerima surat seharusnya dicantumkan sebelum membicarakan isi surat. Dalam hal ini, Lumintaintang (2007: 65) menegakkan bahwa karena pencantuman salam pembuka di dalam surat dinas tidak bersifat wajib, diperlukan ketaatasasan instansi pembuat surat dinas. Artinya, jika suatu instansi sudah memutuskan bahwa surat dinas di lingkungannya tidak mencantumkan salam pembuka, sebaiknya salam pembuka itu tidak dipaksakan masuk ke dalam paragraf pembuka surat. Kesalahan yang terdapat pada contoh (3) dapat diperbaiki sebagai berikut.

(3a) Dengan hormat,

Kami mengundang Bapak untuk menghadiri acara yang akan dilaksanakan pada:

(3b) Dengan hormat,

Kami mengundang Ibu untuk menghadiri acara yang akan dilaksanakan pada:

(3c) Dengan hormat,

Kami mengundang Saudara untuk menghadiri acara yang akan dilaksanakan pada:

4. Demikian disampaikan atas perhatiannya diucapkan terima kasih. (Sumber: Sekretariat Daerah Kota, 6 Desember 2012).

Kesalahan yang terdapat pada contoh (4) disebabkan oleh adanya kata ganti nya yang tidak tepat penggunaannya. Sehubungan dengan itu (Arifin, 2010: 85) menguraikan bahwa kata ganti nya digunakan untuk orang kedua. Jadi, ungkapan atas perhatiannya, atas jawabannya termasuk ungkapan yang salah.

Perbaikan kalimat (4) dapat dilakukan dengan menghilangkan kata ganti -nya seperti berikut. (4a) Demikian disampaikan atas perhatian Saudara, kami ucapkan terima kasih.

(4b) Demikian disampaikan atas perhatian Anda, kami ucapkan terima kasih.

(4c) Demikian disampaikan atas perhatian Bapak, kami ucapkan terima kasih.

5. Demikian disampaikan untuk pelaksanaan. (Sumber: Sekretariat Daerah Kota, 21 Desember 2012).

6. Demikian disampaikan kepada Bapak untuk dimaklumi dan selanjutnya yang bersangkutan melaporkan hasilnya kepada Walikota Makasar Cq. Kepala Kantor Kesatuan Bangsa dan Perlindungan Masyarakat. (Kesbang, 4 Desember 2012).

7. Demikian disampaikan untuk menjadi perhatian, terima kasih.

Kesalahan yang terdapat pada contoh (5) (6) karena kalimatnya tidak lengkap, tidak memiliki subjek. Ketiga kalimat tersebut juga tidak informatif sebab tidak jelas siapa yang melaksanakan dan siapa yang memperhatikan. Kesalahan yang terdapat pada kalimat (5) - (6) dapat diperbaiki sebagai berikut.

(5a) Demikian harapan kami, semoga Bapak dapat melaksnakan tugas ini dengan baik.

(6a) Demikian penyampaian kami, atas perhatian Bapak, kami ucapkan terima kasih.

(7a) Demikian pernyataan) kami, atas perhatian Bapak, kami ucapkan terima kasih.

\section{Simpulan}

Berdasarkan hasil pembahasan yang telah diuraikan) pada bab terdahulu, penulis menyimpulkan sebagai berikut.

Kesalahan diksi yang terdapat dalam dokumen resmi (surat dinas) Kantor Wali Kota Makassar meliputi(a) penulisan kata kordinasi yang tidak tepat, (b) adanya penggunaan kata mubasir, yaitu adalah dan merupakan yang digunakan bersamaan (c) penggunaan ungkapan Bapak/Ibu/Saudara (i) dalam satu surat, yang seharusnya tidak digunakan secara bersamaan, (d) kesalahan penggunaan ungkapan idiomatik, yaitu terdiri dari, seharusnya terdiri 
atas, (e) penggunaan kata penunjuk waktu yang tidak tepat, yaitu kata jam yang seharusnya kata pukul, (f) kesalahan sematik, yaitu penggunaan kata bulan berjalan, yang seharusnya diganti kata saat itu atau bulan tersebut.

Kesalah kalimat yang terdapat dalam dokumen resmi (surat dinas) kantor Wali Kota Makassar menyangkut perihal(a) penggunaan kata menunjuk, yang maknanya tidak tepat. Seharusnya menggunakan kata menindaklanjuti atau berdasarkan. (b) penggunaan makna kata dalam kalimat yang tidak tepat, yaitu adanya penggunaan bersama ini yang tidak tepat karena dalam surat tidak melampirkan apaapa (c) adanya ungkapan dengan hormat yang digunakan sebagai ucapan salam penulis surat untuk penerima surat seharusnya dicantumkan sebelum membicarakan isi surat (d) adanya kata ganti nya yang tidak tepat penggunaannya, dan (e) adanya penggunaan kalimat yang tidak lengkap, tidak memiliki subjek dan kalimat yang tidak informatif

\section{Daftar Pustaka}

Arifin, E. Zaenal. 1996. Penggunaan Bahasa Indonesia dalam Surat Dinas. Jakarta: Akademika Persindo.

Arifin, E. Zaenal dan Mustakim. 2005. Bahasa Indonesia bagi Sekretaris. Jakarta: PT Grasindo.

Arifin, E. Zaenal dan S. Amran Tasai. 2010. Cermat Berbahasa Indonesia untuk Perguruan Tinggi. Cetakan kedua belas. Jakarta: Akademika Persindo.
Arikunto, Suharsimi. 2010. Prosedur Penelitian (Suatu Pendekatan Praktis). Jakarta: Rineka Cipta.

Bratawidjaja, Thomas Wiyasa. 1995. Surat Bisnis Modern. Jakarta: PT Gramedia.

Depdiknas. 2008. Kamus Besar Bahasa Indonesia. Edisi Keempat. Jakarta: PT Gramedia Pustaka Utama.

Finoza, L. (2005). Aneka surat sekretaris dan bisnis Indonesia. Jakarta: Diksi Insan Mulia.

Keraf, Gorys. 1994. Diksi dan Gaya Bahasa. Jakarta: Gramedia.

Lumintaintan, Yahya B.Mungnisjah. 2006/2007. "Pemakaian Bahasa Indonesia dalam SuratMenyurat Dinas". Jakarta: Pusat Bahasa.

Mustakim. 1994. Membina Kemampuan Berbahasa Indonesia Panduan ke Arah Kemampuan Berbahasa. Jakarta: Gramedia Pustaka Utama.

Norissh, John. 1983. Language Learners and Theirs Errors. London: The Macmillan Press. Soejito dan Solchan TW. Surat-Surat Resmi Bahasa Indonesia. Bandung: Remaja Rosdakarya.

Sudarsa, Caca. dkk, 1992. Seri Penyuluhan 2 Surat Menyurat dalam Bahasa Indonesia. Jakarta: Pusat Pembinaan dan Pengembangan Bahasa, Departemen Pendidikan dan Kebudayaan.

Tarigan, Henry Guntur.1988. Analisis Kesalahan Berbahasa. Jakarta: Bandung Angkasa. 
